INTERNATIONAL JOURNAL OF RESEARCHES IN BIOSCIENCES, AGRICULTURE \& TECHNOLOGY ( ) VISHWASHANTI MULTIPURPOSE SOCIETY (Global Peace Multipurpose Society) R. No. MH-659/13(N) www.vmsindia.org

\title{
EFFECT OF BRUCHID INFESTATION ON SEED QUALITY OF CHICKPEA

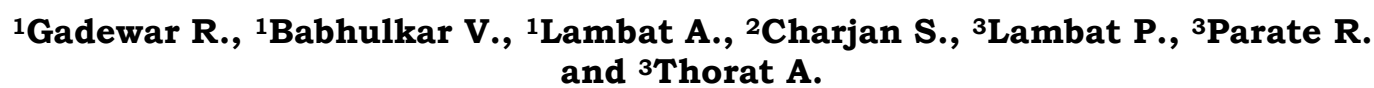

\author{
${ }^{1}$ Sevadal Mahila Mahavidyalaya Nagpur (M.S) India \\ ${ }^{2}$ College of Agriculture (Dr. PDKV's) Nagpur (M.S) India \\ ${ }^{3}$ Shri Mathuradas Mohata Science College, Nagpur (M.S) India \\ Email: lambatashish@gmail.com
}

\begin{abstract}
Experiment was conducted to study the effect of bruchid infestation on 100 seed weight, viability, vigour and incidence of fungal flora of chick-pea during period 2010. The bruchid infested check-pea seeds we collected from one year old crop seeds under following categories viz. , (i) one holed, (ii) two holed, (iii) hole near micropyle, (iv) multi holed and (v) normal seeds. The 100 seed weight, viability and vigour were significantly more in the normal seeds which is closely followed by one holed, two holed, hole near micropyle an dmulti holed seeds. The maximum incidence percentage of fungal flora was found on multi holed seeds as compared to other damaged and normal seeds.
\end{abstract}

Keywords: Bruchid, Chickpea, Seed quality

\section{Introduction:}

Chickpea (Cicerarietinum L) is an important pulse crop of Maharashtra. Like other food grains, chickpea is also stored for varying periods before consumption or next planting season. During storage seeds are badly damaged by bruchids (Yadav, 1985). It's infestation, either originates in the field or in storage and causes serious loss to the seeds. Bruchids being internal feeders, derive their food from cotyledon and lead to gradual loss of the seed. Yadav (1985) reported that chickpea was found to be suitable host to bruchids. In view of this, these studies were conducte dot investigate the effect of bruchid infestation on 100 seed weight, viability, vigour and incidence of fungal flora in chickpea.

\section{Materials and Methods:}

One year old seed of chickpea, cv. G-5 were collected from state Seed Testing Laboratory, Nagpur during April 2004. Bruchid infested seeds were taken out from the sample and egraded into five categories on the basis of hole made by bruchids as (i) one holed, (ii) tow holed, (iii) hole near micropyle, (iv) multi holed and (v) normal seeds. These seeds from each category were separated out for studies on 100 seed weight, germinability and vigour purposes. The germination medium was rolled towel paper.

Results and Discussion:

The data presented in Table- 1 indicated that the 100 seed weight varied significantly and it was highest in normal seeds (24.47 g ) which was closely followed by one holed (21.82g two holed (19.86g), hole near micropyle (18.13g) and multi holed (15.38g) infested seeds. The 100 seed weight decreased with increasing infestation of bruchids. Since the bruchids have been eaten of major portionof the cotyledons which leads to reduction in weight of the seed and inturn affects the seedling establishment because of lack of stored food and is in conformity with the findings of Yadav (1985) and Narayanswamy (1985). The germination followed the same trend of 100 seed weight. It was highest in normal seeds $(73 \%$ followed by one holed $(50 \%)$, two holed (38\%), hole near micropyle $(28 \%)$ and multi holed(15\%). This might be due to infested germ of seeds by brudhid. Seed failed to germinate and thus seed germinability decreased with an increase of seed infestation obtained similar results and he notice dthat normal seeds showed highest vigour index than infested seeds. The fungi Aspergillus sp., Curvularia sp., Fusarium sp., Penicillium sp. And Rhizopus sp. Were founded to be associated with different categories of seeds. The maximum percentage incidence of fungal flora was found on multi holed seeds followed by two holed, hole near micropyle, one hole and normal seeds. Aspergilli was predominant over all other fungi and ranged from 31 to $100 \%$ in case of normal to multi holed infested seeds. Dominance of aspergilla on 
stored grain has been earlier reported by Maheshwari et al. (1985).

The isolated fungi were most inhibitory to germination and seedling vigour (Teggi and Heremath, 1990). The storage fungi directly damaged seed germ and indirectly enhanced the multiplication of storage insects (Kaurav and Prakash, 1980). Yadav and Pant (1975) suggested the role of metabolic wastes of insects in bringing down germination. This indicated that because of infestation of bruchids the 100 seed weight, germinability and vigour decreased drastically and percentage incidence of fungal flora increased. Similar results were also reported by Khare (1972), shivankaret al. (1990) and Lambat et al. (2014).

Table-1: The Effect of bruchid infestation on seed weight, germination vigour and incidence percentage of fungal flora in Chickpea seeds.

\begin{tabular}{|c|c|c|c|c|c|c|c|c|}
\hline $\begin{array}{c}\text { Category } \\
\text { of seed }\end{array}$ & $\begin{array}{c}\mathbf{1 0 0} \text { seed } \\
\text { weight } \\
\text { (g) }\end{array}$ & $\begin{array}{c}\text { Germin } \\
\text { ation } \\
\text { (\%) }\end{array}$ & $\begin{array}{c}\text { Vigou } \\
\mathbf{r} \\
\text { index }\end{array}$ & \multicolumn{4}{|c|}{$\begin{array}{c}\text { Percentage fungi } \\
\text { encountered on } \\
\text { gram seed }\end{array}$} \\
\hline & & & & $\mathbf{1}$ & $\mathbf{2}$ & $\mathbf{3}$ & $\mathbf{4}$ & $\mathbf{5}$ \\
\hline Normal & 24.47 & 73 & 1826 & 31 & & & & 13 \\
\hline One holed & 21.82 & 50 & 928 & 39 & 7 & 2 & 21 & \\
\hline Two holed & 19.86 & 39 & 842 & 62 & 9 & & 35 & 16 \\
\hline $\begin{array}{c}\text { Hole near } \\
\text { micropyle }\end{array}$ & 18.13 & 28 & 671 & 60 & 4 & 2 & 29 & 12 \\
\hline Multi holed & 15.38 & 15 & 427 & 100 & 10 & 6 & 32 & 10 \\
\hline SE (m) & 0.61 & 3.07 & & & & & & \\
\hline CD at 5\% & 1.69 & 9.21 & & & & & & \\
\hline
\end{tabular}

*1= Aspergillus sp, 2 = Curvularia $\mathrm{sp}, 3=$ Fusarium sp, 4= Penicillium sp, $5=$ Rhizopus sp.

\section{References:}

Abdul-Baki, A.A. and J.D. Anderson, 1973. Vigur determination in sobean Seed by multiple criteris, Crop Sci. 13:630-633.

Anonymous. 1976, International rules for seed testing Seed Sci. and Technol. 4: 108

Anonymous, 1985 International rules for seed testing. Seed Sci. and Technol 13:299513.

Khare, B.P. 1972. Insect pests of stored grains and their control in Uttar Pradesh G.B. Pant Uni. Agric. Tech., Pantnagar Res. Bull. No. 5,PP. 152.

Kaurav, L.P. and A. Prakash 1980. Influence of storage fungi on development of lesser gain borer in Paddy. Seed Res. 8 (2) : 137-140.
A. Lambat, S. Charjan, P. lambat and R. Gadewar.2014. Effect of seed treatment with non toxic plant origin substances on seed quality parameters on gram during storage. International Journal Og Researches in Biosciences, Agriculture and Technology 1(2):699-703.

Maheshwari, R.K. , S.K. Mathur and A. Mathur, 1985 Deterioration of lobia (Vigna sinensis Savi) During storage. Seed mycoflora. Seed Res. 13(2) : 107-114.

Narayanaswamy, S. 1985, Effect of pulse beetle damage on seed quality of field bean and pigeonpea. Seed Res. 13 (2): 138-141.

Shivankar, V.J.S.N. Signh, A.A. Khan and P.S. Tomer. 1990. Effect of storage conditions on storability of cowpea. Proc. International conference on Seed science and Technology, New Delhi, 21-25 Feb. 1990. Abstr. No. 2.31

Teggi, R.V. and R.V. Heremath. 1990 Studies on seed mycoflora of shattering and non-shattering types of green gram (Vigna radiate). Seed Res. 18(2): 139-149.

Yadav, T.D. and N.C. Pant. 1975. Effect of feeding by developing stage of Callosobruchus maculatus (fab.) and C. Chinensis. Seed Res. 3: 107-110.

Yadav. T.D. 1985. Feeding behavior of pulse beetles in greengram (Vigna radiate) seeds. Seed Res. 13(2): 35-38. 